\title{
A New Model of German Literacy Comprehension: A Multidimensional Representation
}

\author{
Desti Nur Aini ${ }^{1}$, Kisyani $^{2}$, Agus Ridwan ${ }^{3}$ \\ \{desti.nur.fs@um.ac.id', kisyani@unesa.ac.id², agus_unesa@yahoo.com ${ }^{3}$ \} \\ Universitas Negeri Malang ${ }^{1}$, Universitas Negeri Surabaya ${ }^{2}$, Universitas Negeri Surabaya ${ }^{3}$
}

\begin{abstract}
German literacy comprehension is a new model of knowledge management. It is an intellectual power and potentially developed in education. Knowledge should be empirically investigated and more essentially evolved. This study aims to find a consistent model and focused on the learning of "German literacy comprehension, multidimensional representation". This model develops various comprehension and literacy theory, such as psycholinguistics construction specifically to overcome the problems of learning the German language and being an alternative of less innovative learning. It employs a qualitative method to explore the substantive area to gain new understanding through the situation of German literacy comprehension. It emphasizes that reality can be captured from a text through the process. The qualitative analysis highlights the variety of essential statements, sentences, or quotes that provide an understanding of how the respondents experience the phenomenon of German culture that affects literacy comprehension. The results showed that German literacy comprehension is built based on multidimensional representation which is an activity and a set of abilities that give an opportunity to the respondents, as the reader to skillfully communicate and comprehend according to the lingual mastery, logic, social awareness, and cultural competence development.
\end{abstract}

Keywords: model, comprehension, literacy, German, knowledge management.

\section{Introduction}

Literacy has changed today's life. It may refer to technology, media, language, cultural, even emotional literacy [1]. The core is the read-think-write activities; therefore the meaning of thinking can be the enlargement of community literacy practice based on knowledge and technology in the 21st century [2]. According to Kalantzis \& Cope [3], literacy is a comprehensive introduction. It not only focuses on reading and writing but also evolves the communication of teachers and students. As Kramsch \& Nolden explained[4], the communicative approach and literary content are seen from the view that language as a medium to communicate. In his research, Kramsch refers to the reading activities to the theory of reader's response, which emphasizes that reading is a creative and productive action, not only literacy. Learners focus on the collected information as the result of reading; then they come up with the reaction generated during reading. They can generate dialogic reading activities and creation of meaning. The results of literacy practice in foreign language studies dominated by information literacy and reader's response. Reading in a foreign language is the contour shaping activities of cultural discrepancy in term of meaning. The intertextuality exploration causes foreign language learners to find out where they will alter according to their space within a critical thinking 
framework and intercultural approach. Meanwhile, in the literacy-based learning of German as a foreign language $(\mathrm{DaF}=$ Deutsch als Fremdsprache $)$, there is an integration between the context of Germanic culture, conventions, and social values, through the content and pattern of each text which the learners faced. This kind of literacy mentioned by [5] as literacy which embedded in ideology.

The implementation of the teaching-learning process in German Language Education Department of State University of Malang integratively includes intercultural learning in every lecture. It is indicated by Aini [6] on the research of bicultural literacy, that students have been able to explore the topic and identify new concepts to achieve specific goals. On the aspect of bicultural, students can integrate the cultural aspects involved, with (1) identifying the identity of the foreign culture (German) and compare to the reader's culture (Indonesia), (2) presenting logical perception and objectively identify the identity of the foreign culture (German), and (3) explain events, stories, and incidents that bring the culture and German language. Internalization of universal values can be the foundation of harmony in multicultural life in an educational environment which become the concerned issue in the world of humanities. However, the learners continuously find difficulties to interact either spoken or written. Lingually, the learners are knowledgeable about the standard of grammar, spelling, appropriate use of German convention as a foreign language $(\mathrm{DaF})$. However, in terms of logic and culture, the learners seemed unsuccessfully initiate the learning in the class. Communication, respond to the ideas of others, and critical thinking as personal social skills also has not developed as the target learning. It should be realized in comprehension model as a mental representation [7] of German literacy - mental representation related to how a person builds thinking and mental process regarding the text.

Kern [8] stated that lingual dimension in literacy level means literacy embodied in foreign language curriculum generally focused on the accuracy and convention. On the level of words, the reader requires the encoding process of the expressed-words, in which stand-alone code words shape meaning. Further, on the level of the sentence produces an explicit idea representation which indicated by syntactic and conceptual relations of a phrase. In addition to the syntactic structure, readers should know understanding (sense) of each sentence. Readers need to independently build their knowledge of the perception, which arises in the discourse (text). The reader understands and reconstruct the contextual knowledge, cultivate values and positive attitude in learning. Meanwhile, the explicit notion of text is integrated into the whole sentence, which semantically and pragmatically knowledge supported should be contextually understood in discourse level. The encoding process is included in the role of the learner as the code breaker.

The situation in the text involves the reader into the process of interpretation and information reconstructing based on the understanding previously obtained related to the domain of relevant knowledge. Logical literacy level can be shaped after identifying the complicated part of the text, forming inference and intertext relations. Furthermore, evaluation is required in order to communicate specific concept, even revise and reject a prediction. In this section, learners involved in the role of producer of meaning (text participant).

Literacy involves the awareness of how reading and writing strictly related to the use of language is socio-culturally and pragmatically reviewed [8]. Building a literate person either in micro or macro scale should be able to find a source of new skills and know how to improve knowledge. In addition, learner should be able to develop the thinking skill to face the problems, emerge social skills in collaboration in the classroom, tolerance, communication and responsive towards the ideas of others, critical thinking, resourceful creative imagination, respect to others, care with empathy, democracy, uphold the human rights in general, multiculturalism, and 
responsibility towards the environment[9]. This level discusses the set of social practice performed by others, and learners should follow steps in the text with specific social context the role of the reader as a text user.

This paper defined literacy as the ability to interpret a text with a significant content of Germanic culture through acceptable and understandable ways in the community of Indonesian culture learners. In the perspective of multiculturism, foreign language learning has a process associated with the development of cultural competence, social awareness, and logic. Further, the development of cultural competence as one dimension of the literate community focused on developing competencies including attention, empathy, engagement perspective, tolerance, and communication[10]. This method put text as the media to construct perspective and reader as the text analyst.

Additionally, understanding (comprehension) requires cognitive process and reading behavior, then mediated by the complexity of social practice and cultural knowledge, material and technology of discourse[11]. To gain comprehension, learners adapt, combine, and modify various approaches to get the practices required in the activities of literacy. Freebody \& Luke[12] outlines the model framework of the heuristic, which focused and balanced between the teaching and the curriculum. Another model related to personal literacy comprehension is coding, semantic, pragmatic/interactional, and critical/text analytics. Knowledge and adjustment with the regularity and convention in the text are required to break the code. The code has defined the patterns and relations in semiotics, either oral, written, visual, or multimodal - semiotic system associated with the knowledge, experience, and understanding of the reader's background. The scheme of knowledge and discourse is a cultural resource[13].

Consistently related to semantic dimension, it is considered as resource development to involve the meaning system of the text itself. The reader's comprehension is required to seek inference which is textually correlated and basic knowledge of explicit text or indirectly explained. The learners' duty is not only understanding the text, but also consider the comprehension and process required. More importantly, the pragmatic level views reading learning do not merely skill transmission decoding or understanding process [14], but performing the outcome of reading the text and reading in general. The learners figure out the content of the book and able to describe the character/ character studies. Besides, learners are expected to contribute to drawing appropriate reading method of a text retrospectively.

The last dimension is more appropriate critical analysis in terms of critical reading. The reader's ideological position could be defined as an awareness which requires particular knowledge construction of the reader [14]. The nuances of the reader's reception are captured in this context, as the object, a text is written with specific purpose and tendency towards information. Therefore, it requires the reader critical analysis.

Regarding that dimension, the learning of the German language in Deutsche Literatur course has not met the expected demand of standard. The present recorded activities only implement the theory of related to the normative concept in reading class, without a specific ideological literacy concept. Literacy is stated as a social practice with the potential of technology employment, lingual dimension, logic, social and cultural, therefore learning a model of German literacy comprehension is required. The researcher proposed literacy comprehension model with intact and complete literal competence involvement for skillful learning to think and learning to do. The research problem of this study is how the literacy comprehension of learning in German Language Education at the State University of Malang.

Using four models proposed by Freebody \& Luke is [12] aimed to collaborate those model with critical human dimension, based on lingual, logic, social, and cultural aspects. Collaborating both bits of knowledge are proposed to create a new model in learning, and like 
equipment to help lecturer understanding the literacy development of two cultures (in this case Germanic and Indonesian) comprehensively. Thus, it would facilitate the learning process in class; it is will either to provide a curriculum nor learning resource. In the future, the learners are expected to be in the "unique" position to contribute to the comprehension development and give methodological input associated with the learning process using literacy comprehension model.

The writer proposed the following model to differently create differently point of view in order to construct meaning to comply a literacy comprehension.

Table 1. A Multidimensional Representation Model for Literacy Comprehension

\begin{tabular}{|c|c|c|c|c|}
\hline \multirow{2}{*}{ Comprehension } & \multicolumn{4}{|c|}{ Dimension } \\
\hline & Lingual & Logic & Social & Cultural \\
\hline Coding & $\begin{array}{l}\text { Describe and } \\
\text { mention the } \\
\text { required } \\
\text { information } \\
\text { related to the } \\
\text { textual knowledge } \\
\text { and convention } \\
\text { text. }\end{array}$ & $\begin{array}{l}\text { Describe the } \\
\text { central notion to } \\
\text { extracting from } \\
\text { the collected } \\
\text { information. } \\
\text { - Combine the } \\
\text { central notion to } \\
\text { create a new } \\
\text { concept. }\end{array}$ & $\begin{array}{l}\text { Validate } \\
\text { understanding } \\
\text { and interpreting } \\
\text { information } \\
\text { through } \\
\text { discourse with } \\
\text { others. }\end{array}$ & $\begin{array}{l}\text { Integrate the } \\
\text { involved } \\
\text { cultural aspects, } \\
\text { especially } \\
\text { bicultural/interc } \\
\text { ultural }\end{array}$ \\
\hline Semantic & 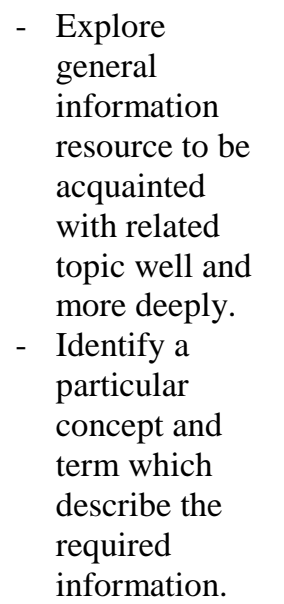 & $\begin{array}{l}\text { Identify related } \\
\text { keywords, } \\
\text { synonyms, and } \\
\text { terms for required } \\
\text { information. }\end{array}$ & $\begin{array}{l}\text { Extract the } \\
\text { information by } \\
\text { investigating } \\
\text { cultural and } \\
\text { social context } \\
\text { where the } \\
\text { information } \\
\text { created. }\end{array}$ & $\begin{array}{l}\text { Emerge futher } \\
\text { intercultural } \\
\text { discussion: } \\
\text { recept and } \\
\text { compare }\end{array}$ \\
\hline Pragmatic & $\begin{array}{l}\text { Figure out the } \\
\text { content which } \\
\text { necessarily } \\
\text { communicated, } \\
\text { compared with } \\
\text { spoken/written. }\end{array}$ & $\begin{array}{l}\text { Giving a clear \& } \\
\text { supportive } \\
\text { statement and } \\
\text { independently build } \\
\text { knowledge from the } \\
\text { perception appeared } \\
\text { from the discourse } \\
\text { (text). }\end{array}$ & $\begin{array}{l}\text { Understand } \\
\text { and reconstruct } \\
\text { the contextual } \\
\text { knowledge and } \\
\text { arise value and } \\
\text { positive } \\
\text { behavior in } \\
\text { learning. }\end{array}$ & $\begin{array}{l}\text { The balance } \\
\text { between } \\
\text { stereotype and } \\
\text { prediction. }\end{array}$ \\
\hline
\end{tabular}




\begin{tabular}{|c|c|c|c|c|}
\hline \multirow{2}{*}{ Comprehension } & \multicolumn{4}{|c|}{ Dimension } \\
\hline & Lingual & Logic & Social & Cultural \\
\hline $\begin{array}{l}\text { Critical } \\
\text { Analysis }\end{array}$ & $\begin{array}{l}\text { Conclude the } \\
\text { meaning on the } \\
\text { semantic level and } \\
\text { restate on their } \\
\text { own words. }\end{array}$ & $\begin{array}{l}\text { Combine the central } \\
\text { notion to create a } \\
\text { new concept by: } \\
\text { - Know the } \\
\text { relation among } \\
\text { exist concept } \\
\text { dan combine } \\
\text { into the central } \\
\text { notion. } \\
\text { - Compare new } \\
\text { knowledge and } \\
\text { previous } \\
\text { knowledge to } \\
\text { determine } \\
\text { additional value, } \\
\text { contraction, or } \\
\text { other unique } \\
\text { characteristics of } \\
\text { the information. } \\
\text { Integrate new } \\
\text { information with } \\
\text { previous } \\
\text { information or } \\
\text { knowledge. }\end{array}$ & $\begin{array}{l}\text { Determine the } \\
\text { impact of new } \\
\text { knowledge on } \\
\text { the system of } \\
\text { individual } \\
\text { value. }\end{array}$ & $\begin{array}{l}\text { Associate } \\
\text { cultural } \\
\text { perspective as a } \\
\text { form of } \\
\text { reflection and } \\
\text { self-reflection. }\end{array}$ \\
\hline
\end{tabular}

\section{Method}

This research is qualitative, which employed psychological phenomenology. Therefore the researcher mostly describes the experience of the informant. The researcher collects the data using the technique of data collection, (1) examination of discourse understanding, (2) in-depth interview, and (3) study of documents). The appropriate procedure of data collection results in the expected data collection. The data analysis of this qualitative research followed these four stages: (1) data collection; (2) data reduction; (3) data presentation; (4) conclusion/ verification. The analysis process is pictured as the following model: 


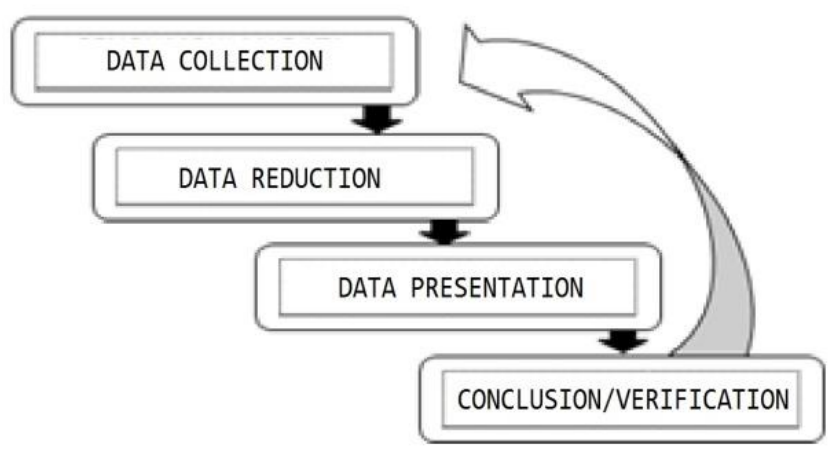

Fig. 1. Data Analysis

The research conclusion focuses on the meaning process, patterns, configuration, causeeffects space, and proportion. The provisional conclusion is verified during the research and consistently examined fact. Research validation is required to get credible results, for instance using triangulation.

\section{Results and Discussion}

One of the points related to Toleranz in the novel titled UFaE! is associated with pragmatics comprehension on lingual stage, logic, social, and culture. The questions (a) "was bedeutetToleranz?", (b) "wiewichtigistToleranzimmenschlichenLeben?", moreover, (c) "wielässtsich das Deutsche Toleranzniveauausdem Text und IhrempersönlichenErfahrungenerkennen?", Discover that the learners not only know the content to communicate compared to the spoken/written but show clear \& supportive statement and build their knowledge from the emerged perception in the discourse (text). The learners can balance the stereotype and prediction as well. Thus, tolerance is considered an important aspect of daily life, and it could be learned. Tolerance is how someone put respect on differences and be able to accept variety even he/she dislike it.

(a) "Toleranz ist ein Merkmal. Das ist im modernen Leben, das von Menschen und verschiedenen Gruppen geprägt ist, und das wird stark unterstützt."

(b) "Toleranz ist wichtig, weil man nicht mit derselben Person lebt, besonders wenn man ganz unterschiedliche Charakter miteinander hat. Und das passiert bestimmt. Toleranz kann man lernen. Es könnte natürlich sein, aber man hat innerlich als Menschen eine Toleranzseite. Wenn man diese Eigenschaft entwickelt, kann es besser sein. Es gibt auch diejenigen, die sich nicht entwickeln können. Die Menschen in Deutschland haben ein eigenes Leben."

(c) "SchließlichkommterzueinemChristentum der Nächstenliebe und Toleranz." (Karl May, Und Friede auf Erden!, Seite 176).

"Für mich wird Toleranz im Menschen gezeigt. Liebe, Harmonie und Gemeinschaft sind zwischen allen Menschen unabhängig von ihrer Zugehörigkeit zu einer bestimmten Rasse und Kultur. Als ich in Deutschland war, habe ich Intoleranz in Deutschland erlebt. Einmal hat die benachbarte Gastfamilie von mir etwas gekocht, einen unangenehmen Geruch verursacht und schließlich die Umgebung gestört. Andere Nachbarn, die sich gestört fühlen, melden dies der

Individual understanding in making sense is his/her interaction with text through the combination of knowledge and personal experience, the information inside the text, and one's evaluative respond. The use of text aims to build possible meaning and creates a link to other 
social and textual field. The communicative approach is taking hand the actual context simulation, and the interaction inside text would be an essential component in learning the way to handle occurrence in real life [12]. Such a notion is predicted in the literary framework, as the combination of factuality and functionality inside the text, the existence of values, and the interpretation of truth and fiction in the narration. The notion would help the learners to understand how texts construct and or destroy identity, and how language develops search alternative meaning. Thus, the width of critical analysis is implicated in interpreting a text.

Literary works believed to be an effective media to spread thoughts and the nuances of culture, even universal values as the basis of multicultural life. A novel in the German language written by Karl May, entitled "Und Friede auf Erden!" tells about traditions, culture, and behavior of community, the environment, and exoticism of the passed area and presents a synthesis towards the sense of East and West at that time. Karl May attempted to present a resolution of the problems of contemporary humanity and how the world views Germany society. Through the work of Karl May, one may see the social and cultural issues through the angle of literary thoughts, and the writer employed lingual, logic, social, and cultural dimension to examine the learners reading comprehension. As Nia stated that text has aesthetic and emotional elements would functionally enrich a person's communication skill, thus the use of prose in learning German as a foreign language is considered in this paper, [15]. In this case, communication skill is how one can predict, improve vocabularies and understand a bunch of words to increase the level of proficiency. Meanwhile, the emotional elements are responded by the readers of prose, because the literary text contains a sign (Signale) of social relations [14]. The sign is represented through a variety of exciting topics in social-cultural and cross-cultural.

\section{Conclusion}

Literacy comprehension is actively connected not only with the fundamental knowledge (Vorwissen) and knowledge of the world (Weltwissen), but also the learners scientific understanding (Sprachwissen). The association is confronted with each other with the read-text (UfaE!), and the text is realized as an action which produces meaning. German literacy comprehension is built based on multidimensional representation which is an activity and a set of abilities that give an opportunity to the reader to skillfully communicate and comprehend according to the lingual mastery, logic, social awareness, and cultural competence development. Activity and a set of abilities focus on the role of the reader not only as code breaker (coding), the meaning producer (semantic), and the text user (pragmatic) but also as the critic (critic analysis). The role is conceptually controlled by a variety of literary dimensions, such as lingual, logic, social, and cultural. The real and potential role shape the literacy comprehension model emerging as knowledge in the classroom.

As a new model in knowledge management, German literacy comprehension: multidimensional representation is expected to contribute towards the knowledge. Become an alternative in less innovative learning routine; German literacy comprehension is used as an information resource in the learning process. The learners' involvement via this model give opportunities to develop competence through various combinations of training, experience, discussion, and reflection. This new model ensures the learners' focus on skill improvement needs. By German literacy comprehension, multidimensional representation is expected to give strategic value in developing knowledge as an excellent sustainable resource. 


\section{References}

[1] A. E. Winans, "Cultivating critical emotional literacy: Cognitive and contemplative approaches to engaging difference," Coll. English, 2012.

[2] Suyono, "Dimensi, jenjang dan asesmen perilaku berliterasi siswa di sekolah," J. Ilmu Pendidik., 2007.

[3] M. Kalantzis and B. Cope, "Literacies pedagogy," Literacies, 2012.

[4] C. Kramsch and T. Nolden, "Redefining Literacy in a Foreign Language Linked references are available on JSTOR for this article : Redefining Literacy in a Foreign Language," Die Unterrichtspraxis / Teach. Ger., vol. 27, no. 1, pp. 28-35, 2016.

[5] B. V. Street, "Literacy in Theory and Practice," Appl. Psycholinguist., vol. Volume 7, no. 2, pp. 171-175, 1984.

[6] D. N. Aini, "Bicultural Information Literacy: Study on The Rewritten Texts by Students of The Department of German Language," in Advances in Social Science, Education and Humanities Research, 2017, vol. 109, no. Aecon, pp. 43-47.

[7] P. M. Page, Handbook of psycholinguistics, Second Edi. London: Elsevier, 2006.

[8] R. Kern, Literacy and Language Teaching. Oxford University Press, 2000.

[9] N. Aloni, Humanistic Education From Theory to Practice. SensePublishers, 2011.

[10] M. Heyward, "From International to Intercultural: Redefining the International School for a Globalized World," J. Res. Int. Educ., 2002.

[11] M. Cole, Cultural Psychology A Once and Future Discipline. Belknap Press, 1996.

[12] P. Freebody and A. Luke, "Literacies programs: Debates and demands in cultural context," Prospect An Aust. J. TESOL, 1990.

[13] T. A. van Dijk, Discourse and context: A sociocognitive approach. 2008.

[14] M. Bechtel, Interkulturelles Lernen beim Sprachenlernen im Tandem. Eine diskursanalytische Untersuchung. (= Giessener Beiträge zur Fremdsprachendidaktik). Narr Francke Attempto, 2005.

[15] S. Nia, Yaser Kheyrkhah; Ghaemi, Hamed; Afraz, "The Effect of Mixed-Up Stories on Vocabulary Learning and Retention of EFL Learners," Mod. J. Lang. Teach. Methods, vol. 3, no. 2, pp. 111-128, 2013. 